\title{
CORROSION OF ALUMINUM CLADDING UNDER OPTIMIZED WATER CONDITIONS (U)
}

by

\section{A. Gibbs}

Westinghouse Savannah River Company

Savannah River Site

Aiken, South Carolina 29808

This report was prepared in connection with work done under Contract No. DE-AC09-89SR18035 with the U.S. Department of Energy. By acceptance of this report, the publisher and/or recipient acknowledges the U.S. Government's right to retain a nonexclusive, royalty-free license in and to any copyright covering this report, along with the right to reproduce and to authorize others to reproduce all or part of the copyrighted report.

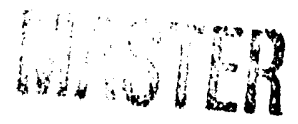




\section{DISCLAIMER}

This report was prepared as an account of work sponsored by an agency of the United States Government. Neither the United States Government nor any agency thereof, nor any of their employees, makes any warranty, express or implied, or assumes any legal liability or responsibility for the accuracy, completeness, or usefulness of any information, apparatus, product, or process disclosed, or represents that its use would not infringe privately owned rights. Reference herein to any specific commercial product, process, or service by trade name, trademark, manufacturer, or otherwise does not necessarily constitute or imply its endorsement, recommendation, or favoring by the United States Government or any agency thereof. The views and opinions of authors expressed herein do not necessarily state or reflect those of the United States Government or any agency thereof.

This report has been reproduced directly from the best available copy.

Available to DOE and DOE contractors from the Office of Scientific and Technical Information, P.O. Box 62, Oak Ridge, TN 37831; prices available from (615) 576-8401, FTS 626-8401.

Available to the public from the National Techncial Information Service, U.S. Department of Commerce, 5285 Port Royal Rd, Springfield, VA 22161. 
UNCLASSIFIED

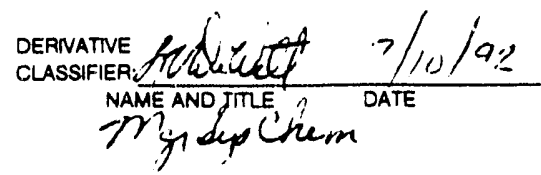

July 8, 1992

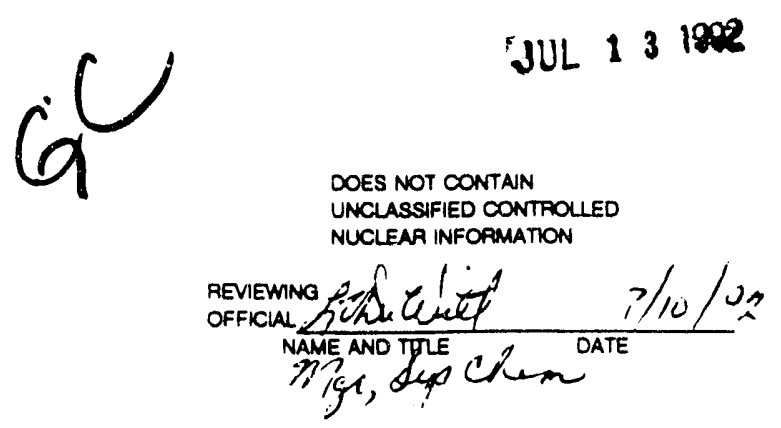

CC: P. D. Rice, 704-C

R. W. Garner, 704-P

B. R. Rankin, 704-C

H. F. Allen, 707-C

F. D. Benton, 707-C

L. V. DoWitt, 707-C

E. W. Baumann, 773-41A

J. P. Howell, 773-41A

Files, 707-C

Document Coordinator (2), c/o Nancy Davis, 705-1C

\section{CORROSIOEN OF ALUMIUUM CLADDING UNDER OPTIMIZED WATER CONDITIONS (U)}

\section{SUMMARY}

Experience at SRS, ORNL, BNL, and Georgia Institute of Technology involving irradiated aluminum clad fuel and target elements, as well as studies of non-irradiated aluminum indicate that some types of aluminum assemblies can be kept in a continually well-deionized water atmosphere for up to 25 years without problems. SRS experience ranges from 2.75 years for the $\mathrm{L}-1.1$ charge kept in deionized $\mathrm{D}_{2} \mathrm{O}^{1}$ to greater than 10 years for assemblies stored in the Receiving Basin for Off-site Fuel (RBOF) ${ }^{2}$. Experience at Georgia Institute of Technology reactor in Atlanta yielded the longest value of 25 years without problems. The common denominators in all of the reports is that the water is continually deionized to approximately $2 \mathrm{M} \Omega\left(2 \times 10^{6}\right.$ ohms) resistivity and the containers for the water are stainless steel or other non-porous material. This resistivity value is equivalent to a value of 0.5 micromhos or microsiemens conductivity and is reagent grade $\mid 1$ quality water. ${ }^{3}$

Copies of pertinent SRS documents are attached. 
RRD-RTS-920119

page 2

\section{DISCUSSION}

The conditions of low temperature and extended time under controlled conditions are those normally found in research reactors. Since many of the $U$. S. Universities and national laboratories that operate research reactors use aluminum clad fuel and heavy water, a number of calls were made on June 25, 1992. Tom Prach of Brookhaven National Laboratory reported that they have had irradiated fuel in their storage channel in light water for 8 years, with no problems. The aluminum is type 6061. The maximum temperature of their reactor is $55^{\circ} \mathrm{C}$. BNL deionizes to $2 \mathrm{M} \Omega$ continually, with deionizer regeneration at $1.5 \mathrm{M} \Omega$. The canal where the fuel is stored in stainless steel. BNL also has coupons of 6061 aluminum tied to stainless steel in the canal. These coupons have been in place since 1977, and are removed for examination annually. They have not observed any excessive corrosion on these coupons to this date. BNL has never observed fission product activity, turbidity, or any other evidence of aluminum corrosion in their storage basin water.

According to Burney L. Corbett of ORNL, there has been irradiated HFIR reactor fuel in their basin since 1986. They are concerned about the possibility of corrosion, even though they have never seen any fission products, since they cannot visually inspect inner surfaces. They examined the outer surfaces in 1991 and found no evidence of corrosion. HFIR deionizes their water in the stainless steel basin to 0.8-1.2 $\mathrm{M} \Omega$ continually. The aluminum cladding on HFIR fuel is type 6061.

R. A. Karam of the Georgia Institute of Technology reported that they have fuel clad in type 1100 aluminum which has been in the reactor in deionized heavy water for 25 years. No evidence of corrosion, visual or by leakage of fission products, has been seen. The temperature range this fuel has been exposed to is ambient to $45^{\circ} \mathrm{C}$.

At SRS, L reactor was charged in September, 1983. An inspection of the assemblies was carried out in 1985 prior to restart'. The fuel in this charge was run until May, 1986. The inspection showed no corrosion or other degradation of the cladding. Records of moderator radioactivity retrieved from DPSOL 6101 samples show no unexpected activity during this charge. Conductivity was maintained in the reactor vessel at approximately 2.5 micromhos $(0.4 \mathrm{M} \Omega$ resistivity) by acid addition to maintain the $\mathrm{pH}$ value near the minimum for aluminum oxide dissolution.

In RBOF, which has epoxy coated walls and a stainless steel floor and continual deionization, irradiated aluminum clad fuel assemblies have been stored for more than 10 years with no evidence of corrosion ${ }^{2}$. The aluminum storage racks in this facility have been in place for 30 years with no visual evidence of corrosion. Conductivity is maintained at approximately 0.07 micromho (15 M $\Omega$ resistivity). 
In reference 2, aluminum corrosion is reported as being on the order of $0.15 \mathrm{mil} / \mathrm{yr}$ at $40^{\circ} \mathrm{C}$ in deionized water. The type of aluminum and quality of water are not specified, but it is a good rule of thumb. The types of aluminum used in SRS reactor assemblies have been selected for their corrosion performance at high temperatures. If SRS is to go to low temperarure conditions, a change of aluminum alloy for cladding will improve the corrosion resistance. For example, type 1100 aluminum has excellent corrosion resistance at low temperatures in high purity water ${ }^{4}$, as does type 6063. Type 8001 aluminum is designed for high temperature applications and the alloying elements are cathodic to aluminum at low temperatures. Type 6061 aluminum which has been used in most of the research reactors is very similar to 6063 and is used for structural strength and resistance to corrosion at low temperatures.

\section{CONSEQUENCES OF CORROSION}

If there is through-wall corrosion of an assembly in the reactor, there will be release of fission products to the moderator and blanket gas. Corrosion is usually a slow process and the penetrations are normally small, so increases in activity should be noticeable over an extended period on the many in-reactor monitors and grab samples before becoming an issue in operation, releases, or ALARA. ihe fission products will be removed from the moderator by the purification system and will not result in increased dose to the public. The fission noble gases released would be a small fraction of what SRS has been given permits for under full operation. An increase in tritium level in the reactor moderator from a target corrosion would probably not be seen at the present levels of tritium in $\mathrm{K}$ Area moderator $(8 \mathrm{Ci} / \mathrm{L})$.

At high temperature operation, SRS occasionally saw self-healing of pin-point failures, due to oxide formation. It is questionable whether this mechanism will work at low temperature operation. Finding and discharging an assembly which has failed because of cladding pitting corrosion may be a difficult to impossible job, given the lack of sampling locations to specific locations in the core. While attempting to isolate the leaking assemblies, SRS should be prepared to run with known failures up to some agreed upon activity level to allow the longest use of the charge.

\section{RECOMMENDATIONS}

Aluminum clad fuel elements can be stored and/or run for at least 5 years without excessive corrosion in non-porous vessels containing continuously deionized water. The water should be deionized to $2 \mathrm{M} \Omega$ resistivity if the reactor is not operating. During reactor operation acid additions need to be made to provide the optimum pH for maintaining the aluminum oxide coating and the resistivity will fall to $0.4 \mathrm{M} \Omega$. A change from type 8001 to 6063 or 1100 cladding will improve the probably of long term service at low temperature conditions. SRS should have an agreement with the regulatory bodies that the current Technical Specifications on activity levels be maintained even at low power/temperature conditions to permit longest use of a charge. 
RRD-RTS-920119

page 4

\section{REFERENCES}

1. RTR-2373, L-1.1 Cladding Inspection and Test Program Results, S. R. McMahan, June, 1987. 2. WSRC-TR-92-187, A Corrosion in SRS Storage Basins (U), M. C. Thompson, T. S. Rudisill, April, 1992.

3. ASTM Specification D1193, Standard Specification for Reagent Water.

4. SRT-MTS-92-3011, Storage of Aluminum Clad Fuel and Target Alloys in the SRS Disassembly Basins (U), J. P. Howell, April, 1992.

\section{KEYWORDS}

Technical

Aluriinum

Corrosion 
RTR 2373

June 11,1987

TO: G. F. MERZ, 703-A

FROM: S. R. HAMAHAN, 105-L

\section{L-1.1 CLADDING INSPECTION AND TEST PROGRAM RESULTS}

\section{INTRODUCTION}

The I Reactor was charged in September, 1983 in preparation for restart. After the assemblies had been in the reactor moderator for two years, an inspection and testing program was conducted to ensure the assembly cladding integrity prior to startup. This report presents the results of the inspections.

\section{SUMMARY}

A testing and Inspection program recommended in RTM 4712 was conducted on the L-1.1 charge. The program consisted of visual inspections for gross mechanical damage and metallurgical analysis to determine possible cladding corrosion. Fifteen Mark 16B assemblies were removed from the tank and visually inspected by the Equipment Engineering Department (EED). The top, bottom and middle slug pairs (Inner and outer) frow three Mark 31A assemblies were analyzed for pitting, cracking, cladding thickness, aluminum oxide layer thickness and bond strength by EED's Metallurgical Lab at 322-M. EED evaluation showed that the Mark 16B and Mark $31 \mathrm{~A}$ assemblies were not adversely affected by two years exposure to moderator.

\section{DISCUSSION}

In September 1983, the L Reactor was charged with a typical E-D lattice consisting of Mark 16B fuel and Mark 31A targets. The extended exposure to moderator prior to $L$ restart in October 1985 caused concerns about possible corrosion of assembly cladding. A testing and inspection program was developed for the $L-1.1$ charge consisting of visual inspections for gross mechanical damage and metallurgical analysis to determine possible cladding corrosion (Reference 1).

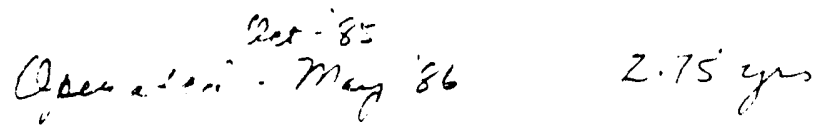


RTR-2373

Page 2

June 11,1987

An Initial visual Inspection was performed in June 1984 on sixteen assemblies from the center of the reactor as part of a debris inspection program (Reference 2). Results of the inspection showed only minor scratches of the type that normally occur during charge and dischage operations. All of the scratches were within the maximum allowable depth of 0.010 inches.

In September 1985, fifteen Mark 16B assemblles (Table 1) were removed and visually inspected by EED for blisterlng, gross corrosion, scratches, pitting, rib wear marks and color. No serlous problems were found in any of the Mark 16B assemblles. No blistering of the cladding was noted. All scratches were well within the 10 mil specification and all pitting was less than the allowable 20 mil depth. Normal rib wear marks from charge and discharge operations were found on all the assemblles (Reference 3 ).

Additfonally the outer diameter of three Mark 15B assemblies was measured, and found to be within the tolerance of $3.700+0.015$ inches. One fuel tube required repeated efforts before It could be successfully discharged. Some galling occurred between the Fuel Sleeve Housing (FSH) and the aluminum cladding near the top of the tube. The galling was smoothed before the assembly was recharged. FSH's for the fifteen inspected Mark 16B assemblies were removed and Inspected for mechanical damage and possible debris remaining from the SRL Hydraulic tests in May 1985 (RI-L-580). All the FSH's were found to be in good condition without any debr1s (Reference 4).

Three Mark 31A assemblies (Table 2) were removed from the tank, destacked and visually inspected by EED. Minor scratches and pitting within allowable 1 imlts were found (Reference 5). The top, bottom and middle slug pairs (Inner and outer) were sent to the Metallurgical Lab at 322-M for visual metallographic and mechanical examinations. The nine slug pairs were Inspected for surface defects such as cracks and blisters, and metallurgically evaluated for cladding thickness, surface aluminum oxide layer thickness and cladding-to-core bond strength. EED evaluation showed that the quality of the uranium core and the mechanical strength of the core-to-cladding diffusion bond were not degraded by prolonged exposure to moderator. The cladding thickness for all slugs was above the 0.020 inch minimum acceptable value. The aluminum oxide layer was found to be of similar thickness $(0.0001$ - 0.0002 inch) to current acceptable slugs (Reference 6). 
RTR-2373

Page 3

June 11, 1987

\section{REFERENCES}

1. Fowler, R. C., L-1.1 Cladding Inspection and Test Program, RTM 4712, June 24, 1985 .

2. McAllister, J. E., Results of the Debris Investigation Program For L-Reactor, RTR-2242, October 18, 1984.

3. Peters, J. J., Mark 16B Slugs, EED 85-0473, October 23, 1985 .

4. Wood, D. C. and McMahan, S. R., Assembly Cladding Inspect1on, Job Plan CisD 13, September, 1985.

5. Vesse1, E. M., Mark 31 Asisembl1es, EED 85-0492, November 7, 1985.

6. Stanaland, V. A. and Eberhard, B. A., L-Reactor Mark 31 A Target Slugs, EED 85-0458, October 28, 1985. 
RTR -2373

Page 4

June 11,1987

\section{TABLE 1}

ASSEMBLIES FOR DESTRUCTIVE METALLURGICAL ANALYSIS

\begin{tabular}{|c|c|c|c|}
\hline ASSEMBLY & $X-Y$ & OLC & ELOW ZONE \\
\hline MK31A & $33-57$ & 7 & 7 \\
\hline MR31A & $15-45$ & 189 & 7 \\
\hline MK31A & $37-15$ & 279 & 8 \\
\hline
\end{tabular}


RTR -2373

Page 5

June 11, 1987

TABLE 2

MK16B ASSEMBLIES FOR VISUAL CORROSION INSPECTION

$\begin{array}{ccc}\frac{X-Y}{23-81} & \text { OLC } & \text { FLOW ZONE } \\ 31-81 & 358 & 2 \\ 20-72 & 218 & 2 \\ 24-72 & 210 & 1 \\ 32-72 & 214 & 1 \\ 43-69 & 110 & 1 \\ 25-63 & 238 & 2 \\ 39-63 & 106 & 1 \\ 12-60 & 124 & 1 \\ 36-54 & 198 & 1 \\ 27-51 & 59 & 1 \\ 22-48 & 6 & 1 \\ 26-42 & 34 & 1 \\ 38-30 & 26 & 1 \\ 17-39 & 148 & 1\end{array}$




\section{WESTINGHOUSE SAVANNAH RIVER COMPANY SAVANNAH RIVER TECHNOLOGY CENTER}

WSRC-TR-92-187

April 9. 1992

To:

A. L. Blaacett, 773-A

From: M. C. Thompson, 773-A NLCF

T. S. Rudisill, T73-A TSR

\section{Al Corroajon in SRS Storage Basins (U)}

\section{Derivative

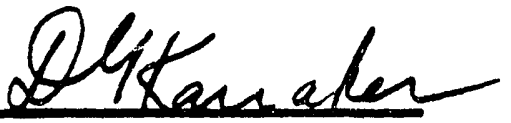

\section{SUMMARY}

SRS has many year of experience with storage of aluminum-cled fuels and targets in two different types of storage basins: the resctor diansembly basins and the Receiving Basin for Offsite Fuels (RBOF). The basins bave different water chemistry resultiog in different rates of aluminum corrosion in the basins. Consequently, the leagth of time that Al-clad fuels or targets can be stored safely depends on the basin where the material is sored On the basis of SRS experience. Al-clad fuels cannot be stored for mose then 18 monthe in a reactor dissecembly basin without leaking, but can be stored for at lean 10 years in a basin such a RBOR. In one case, plutonium wes leached from targets into resctor beain water. demonstrating thas loag term storage could lead to lose of finile macarial coatrol. Taiwanese Resanreh Rexctor (TRR) fuel is a special cace in which the Taiwanese have experienced problems with corrosion of the fuel and have used dry storage to preveat coatamination of their basin. TRR hel is brown to leak in less than four yeans therefore, TRR fuel should sot be stord $b$ say water basin for more thas four years. All Al. clad fuels presently acred in the resctor basins should be removed and reprocessed or placed in ary rorage as soon as possible.

\section{INTRODUCTION}

Proposals have been medo to stop processing Al-cled resctor tuels and targets in existing SRS separations fecilities. The proposals asoume that these materiale can be stored in existing water basins until they can be placed in a repository or reprocesed in Complex 21 facilities. Neither of these options will be available until sometime anter the year 2000 . This repon was prepared to address the technical issues and the safety of long term storage of Al-clad 
fuels and targets in existing water basins at SRS. In addition, altematives to storage in water basins are presented.

\section{DISCUSSION}

\section{RBOF}

SRS has many years of experience with the handling and storage of Al-clad fuels in two differeat types of water basing. 1.8 The first type of basin is the RBOF storage facility which is a concrete pool with an epoxy coatins to prevent leaching of concrete by water in the basin. ${ }^{8}$ Aluminum racks and buckets are used to store fuel and other materials. Aluminum racks reduce corrosion of Al-clad fuels by galvanic action. Mixed bed ion exchange equipment is operated continuously to remove fission products, maintain deionized water, and keep the $\mathrm{pH}$ within the prescribed limits (5 to 9). The wide pH limits are acceptable because the water is deionized. If the deionizers were not operated continuously, the ion content and corrosivity of the basin would increase. RBOF is a small facility about 30 years old which is close to the end of its useful life. There are places where the coating on the basin walls is no longer adhering, although no obvious holes can be seen. Table 1 gives the capacity of RBOF and a summary of the locations occupied by different fuel types.9.10 The majority of the spece is allotied to stainleas steel (SS)

and Zracled fuels. These fuels are safe to store for long periods of time in RBOF as long as the water chemistry is muintained.

RBOP has good experience with the storage of Al-clad fuals and arget assemblies. Althout fuels reaerally processed within yene of receipt. some Aleled twat thre bee gored in RBOf lor more the 10 yean without evidence of si unlichil credein penetrition 29 evideded by low fission product release into the water (see Table 2). A number of apecil A-clad reactor assemblies for transplutonium isotope production have aleo bees stored for more than 10 years without significant deteriorcion. The aluminum racks in RBOF do not show sigms of significant corrosion after almost 30 years of submersion. Corre on of aluminum in deionized water is slow $\left(0.15\right.$ mils/year a $40^{\circ} \mathrm{C}^{11}$ ) so oni would not expect to sec decterioration of the thick $\mathrm{A}$ stornge recks. However, if the deionizers wers aor operated. corrosion would be much more rapid as compounds of fiasion produces build up in the basin water.

TRR fuel has a hiatory of corrosion and leakage when sored under water for four years. 12 The Taiwanese store the fuel dry because so many failures bave been experienced during storage under water. No information was found on the waser chemistry of the Taiwanese basin. The fuel has been scheduled for rapid reproceasing a SRS to prevent failures during storage in RBOP and the subsequent release of fission products into the water.

\section{Reactor Disassembly Basins}

The second type of fuel $\because$ rage facility a SRS is the resctor disussembly basins which are untreated conc is pools in direct contact with the basia water. 1.7 The basins are filled wit water from the Savannah River that has been clarified and filtered, then adjusted in the basin to a $\mathrm{pH}$ of $7.3 \pm 0.6$ with $\mathrm{HNO}_{3}$ or 
NaOH. 3 The pH limits have been tightened since 1980 to $7.3 \pm 0.3$. The basin water leaches ions from the concrete. increasing the corrosivity of the water. Mixed bed ion exchenge equipment is operated on a regular (but not continuous) basis to remove fission products from the fuel, and ions from concrete. The basin is purged with fresh river watep whea the tritium concentration exceeds a preset limit. Tritium caters the basins as a result of the film of moderator on fuel discharged from the reactors. 3

Fuel tubes are suspeaded from stainless steal bangers. 3 Target sluas are stored in stainless steel buckets 6 SRS reactor fuel tubes and targets are designed with a cladding thickness which allows storage in the disassembly basin for about 9 months before corrosion penetrates the cladding. The tubes were designed this way to minimize the amount of aluminum going to waste after separation of Euclear materials. The operating philosophy was in disassemble tubes and ship them to Separations within 9 montha so thas les, ing of fission
products into the basins was minimized.

Table 3 shows the inventory of Al-clad fuels and targets stored in SRS reactor besins, and the dave seored. In addition to the fuel and hareen abown in Table 3. californium and cobalt slug have been stored for more then 20 years. Reactor basins have a much higher ion content leadies to bizhes corrosion rates. The stainless steel hangers and buckets used for storage aleo lead to rapid corrocion by galvanic sction between the aluminum and reel.1.7 Storage of SRS fuble or targats for 18 mooths is confirmed to here resolted in significant penetrations and iscreased fission product activity in the water.6 Cladding penctrution bas been obearved is earty as 1.3 moats with the relesse of fiasion products and plutonium into the wator. 3 Receaty whes the ion exchangers in K resctor bacin were not opernted dus to uperedes and the efforis to restin the resctor, the water chemistry weat out of coatrol ( $\mathrm{pH}=8.6$ )

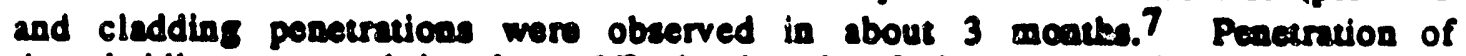
the cledding occurred in about $1 / 3$ the length of time expected wben the $\mathrm{pH}$ is within limits. Figure 1 shows a photomicrograph of a through- wall pit.5.7 Tests initiated to obtain additional data on corrosion bave showe that pitting corrosion can be significant even with the control of pli.7 in the toun corrosion due to selvanic ection was prevented by electrical isolation of the corrosion coupon. In addition. Mat 31 unget slues stored in L recetor basin for more then 3 years show extensive corrosion evea though the basin water. chemistry bas been in control the eatire time of storage. 6

\section{RECOMMENDATIONS}

Aluminee clad fuck and targets cannot be stored in SRS reactor beain for longer then 18 months without penetration of the cledding and release of fission prodects and ponsibly nissile plutonium. Although fuels bave been stored in RBOP for 10 years. TRR fuel bas a history of leating due to corrosion and should not be stored for more than a few years. All Al-clad foels presently stored in the reactor basins should be removed and reprocessed or placed in dry storage as soon as possible. The TRR fuels should also be reprocessed as rapidly as possible to preveat leakage due to corrosion. 


\section{REFERENCES}

1. A. H. Peters, "Fuel Jacket Corrosion in Plant Disassembly Basins," DP.57. E. I. du Pont de Nemours, Savannah River Laboratory, Aiken, SC, June, 1954.

2. M. W. Zacharis and D. R. Becker, "Disassembly Basin Corrosion Literature Search," RTR-1727. Westinghouse Savanaah River Company, Aikea, SC, August 31. 1977.

3. C. D. Wollam, "Accelernted Corrosion of Target Assemblies in the Disassembly Basins," RTR-1939. Westinghouse Savannah River Company. Aiken, SC, October 15, 1980.

4. R. S. Ondrejcin. "Corrosion of Aluminum Reactor Components (U)," WSRC-RP.89-539. Westinghouse Savannab River Company, Savanaab River Laboratory, Aikea, SC, July 17, 1989.

5. R. S. Ondrejcin and D. E. Rawl, "Corrosion of Aluminum Components in K-Reacior (U)." WSRC-TR-90-291, Westinghouse Savanaah River Company. Savanath River Laboratory, Aiken, SC, July 13, 1990.

6. J. J. Banke. "Imadiated Slug Corrosion Study (U)." WSRC-TR-90-42-030, Westinghouse Sevanneh River Company, Aiken, SC, May 30. 1991.

7. J. E. Marre "Corronion of Aluminum Componeare in SRS Fuel a Target Storage Basins. (U)," SRL-MTS-923016. Westinghouse Savannal River Company, Savannah River Laboratory, Aiken, SC. February 19, 1992.

8. H. M. Kelley, Systems Andysis - 200 Area, RBOF Operations, Savannah River Plant, DPSTSY-200-4, E. I. du Poat de Nemours. Savannah River Laboratory, Aiken, SC, February, 1977.

9. A. N. Holloway, "RBOF Fuel Storage Array," NMP-SRB-92-0085, Westinghouse Savannah River Company. Aiked, SC, February 29, 1992.

10. S. W. Stump, "Inventory of U-Al Fuels at RBOF (U)." NMP-STH-91-0175, Westinghouse Savannah River Company, Aikea, SC, August 29. 1991.

11. Letter. A. T. Clat to S. D. Smiley, "Corrosion of Storage Racks in RBOF", December 10, 1962.

12. Abernce: Enery Data Base-82-027827, Y. D. Chang and C. C. Chu. "Examination Report on TRR Irrediated Fuel Rod A-254X Severely Corroded Duriog Stonge." Ho Tzu K'o Hsueb (Triwan), 17, 201, 1980. 


$$
\begin{gathered}
\text { Table } 1 \\
\text { RBOF Capacity and Usage } \\
\text { Inventory Date - Marsh 1, } 1992
\end{gathered}
$$

\author{
Type Cladding \\ SS and $\mathrm{Zr}$ \\ Al \\ Unallocated \\ Nuclear Safety Rows
}

Totals
Spaces Allotted

1773

809

215

98

2895
Spaces Occupied

1574

603

0

0

2177 
Table 2 RBOF Al-Clad Fuel Inventory

Inventory Date • March 1, 1992

Non-Production Fuels

Percent Total

Year of

U.235 Uranium Pu-239 Oldest Processing

Reactor Enrichment (Kg) (Kg) Receipts Option

$\begin{array}{cccccc}\text { EBR-I } & 0.19 & 22105.3 & 76.135 & 1986 & 221 \cdot \mathrm{F} \\ \text { JMTR-JRR } & 88.17 & 16.8 & 0.000 & 1989 & 221 \cdot \mathrm{H} \\ \text { NEREDDE } & 19.79 & 35.4 & 0.000 & 1982 & 221 \cdot \mathrm{H} \\ \text { ORR } & 82.20 & 20.6 & 0.000 & 1988 & 221 \cdot \mathrm{H} \\ \text { ORR-LEU } & 15.75 & 95.0 & 0.000 & 1989 & 221 \cdot \mathrm{H} \\ \text { RHF } & 81.97 & 25.3 & 0.000 & 1982 & 221 \cdot \mathrm{H} \\ \text { SFF } & 77.48 & 34.0 & 0.000 & 1988 & 221 \cdot \mathrm{H} \\ \text { SFO } & 93.19 & 100.8 & 0.000 & 1984 & 221 \cdot \mathrm{H} \\ \text { TRR } & 0.60 & 55901.3 & 14.620 & 1990 & 221 \cdot \mathrm{F}\end{array}$

TOTALS $\quad 459.34 \quad 78334.690 .755$

SRS Reactor Assemblies

(No. 2 Cask Basin)

Assembly Number of Year Stored

Designation Assemblies at RBOF

$\begin{array}{ccc}\text { MK-18A } & 65 & 1979 \\ \text { MI-42 } & 16 & 1983 \\ \text { MK-16 } & 1 & 1984 \\ \text { OX-2 } & 1 & 1984 \\ \text { US-1 } & 1 & 1983 \\ \text { US-2 } & 3 & 1983\end{array}$


출 으 몬
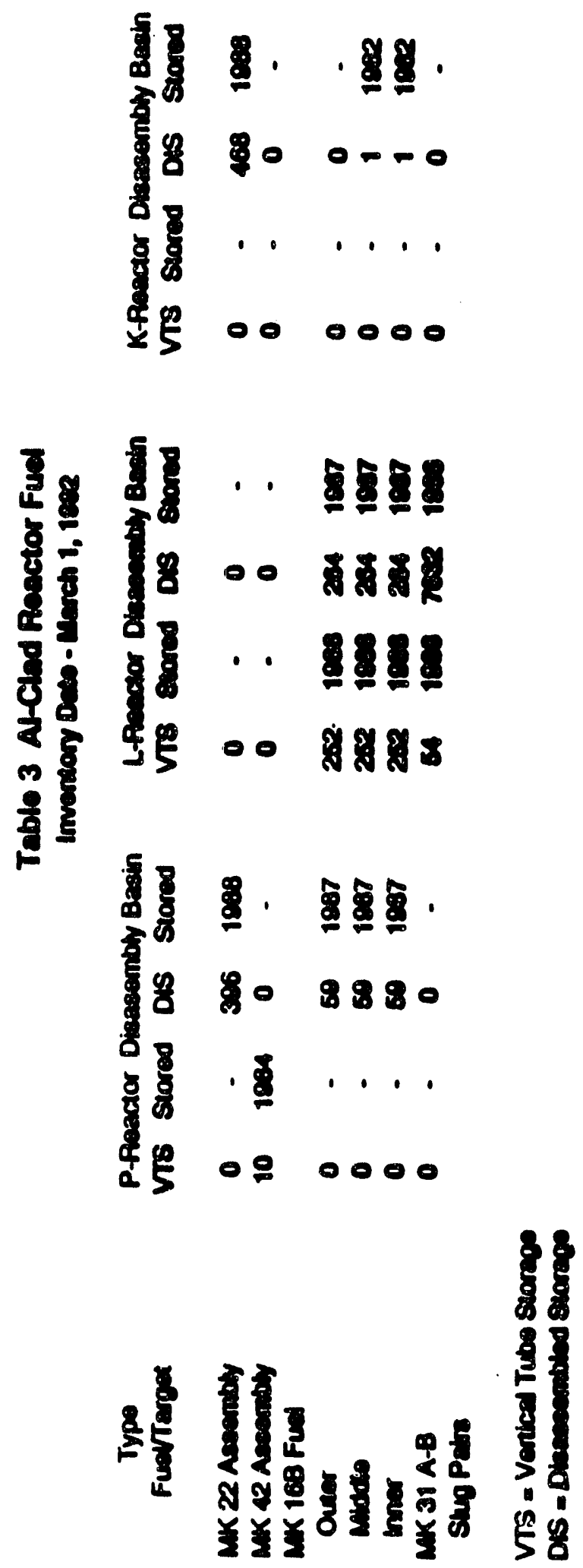


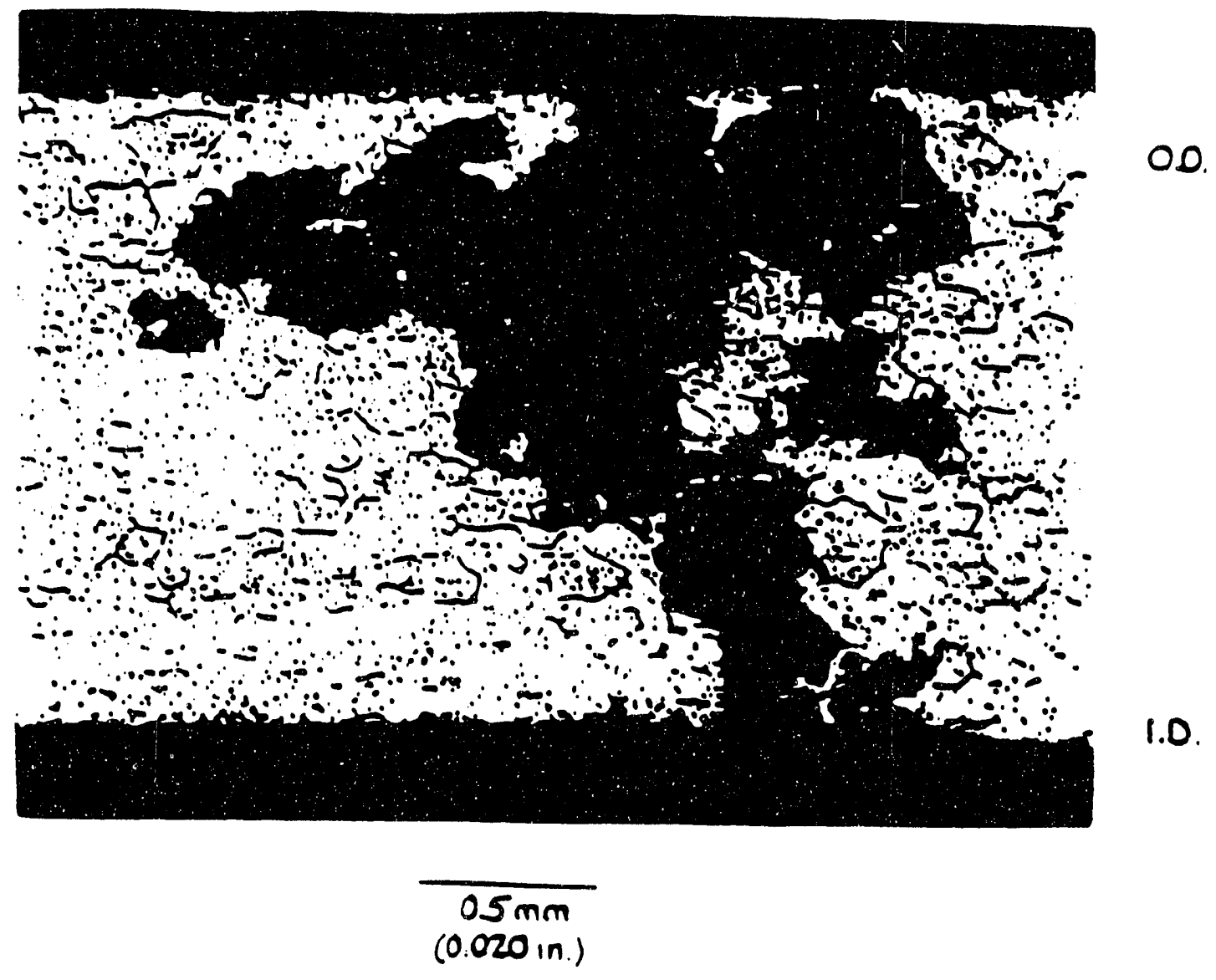

Figure 1 Through-wall Pitting Observed in Type 6063 Aluminam Slecre Housing 


\section{Westinghouse Savannah River Company Inter-office Memorandum}

April 30, 1992

TO: T. L. CAPELETTI, 773-41A 141

FROM: J. P. HOWELI, 773-41A/134

(5-3567

Approved:

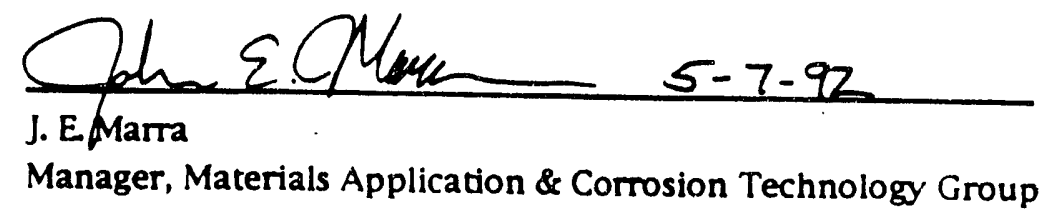

$\frac{\text { D. Themen Ranhi }}{\text { Authorized Derivative Classifier }} \frac{5-7-92}{\text { Date }}$ STORAGE OF ALUMINUM CLAD FUEL AND TARGET ALLOYS IN THE
SRS DISASSEMBIY BASINS (U)

\section{Summary}

Corrosion protection of aluminum clad fuel and target assemblies stored in the SRS disassembly basins is an important consideration because cladding penetration can result in fission product release to the basins. Implementation of the following key changes in facilities and operations could reduce the likelihood of corrosion of Mark 22 assemblies stored in the basins.

1. Replace the stainless steel hangers with aluminum or insulated hangers to eliminate the galvanic couple which can accelerate pitting corrosion of the assemblies.

2. Improve the basin water chemistry. Remove the sludge build-up on the basin floor which contains iron and other corrosive ions and continuously emits these to the basin water. Iron and copper ions promote pitting of the assemblies.

3. Run the de-ionizers continuously to remove the heavy metal ions to maintain this concentration as low as possible. 
T. L. CAPELETTI

SRT-MTS-92-3011

Page 2

April 30, 1992

4. Examine other aspects of the water chemistry like $\mathrm{pH}$ to determine optimum conditions to protect the aluminum without destroying the concrete basin.

Current information suggests that improved water chemistry like that existing in RBOF has permitted storage of aluminum components for up to ten years in that basin. With even purer water chemistry like that of the reactor moderator, corrosion problems have been essentially non-existent.

Storage of aluminum clad fuel and target assemblies in the SRS disassembly basins has been successful over the years of plant operations. However, pitting corrosion of the aluminum alloys has been a periodic problem when the alloys have been in extended storage awaiting processing by the Separations Department. Basin water chemistry has been controlled in the past and the present, but the prime protection against breaching of the aluminum cladding has always been the shipment of materials to the 200-Area after the minimum required period.

Between 1974-1977, at least four distinct cases of cladding penetration and fission products release to the disassembly basin occurred. Based on these and other incidents, and the corrosion studies conducted on-site over the past few years, pitting corrosion may occur on assemblies stored long-term under existing operating conditions and basin water chemistry environments cannot be ruled out. Pitting corrosion is random in nature and is difficult to quantify. Consequently, based on historical results, through wall penetrations may occur in three months or sooner, depending on water conditions.

Previous successful storage experience with Mark 42 assemblies for up to three years is not directly applicable to long-term storage of Mark 22 assemblies. For example, the Mark 42 use of all 6063 aluminum which is less susceptible to pitting corrosion in the basin environment than 8001 and 1100 alloys used in Mark 22 assemblies. In addition, the galvanic couple between the stainless steel hangers and aluminum assembly was possibly reduced or eliminated by storage in the sleeve-housings. This type of storage minimized dents and scratches on the cladding materials. Removal of the protective oxide coating exposes the bare aluminum and makes these sites available for initiation of pitting corrosion. Finally, the Mark 42's received seven separate irradiations and discharges to the basin which may have improved the protective nature of the oxides.

\section{Introduction}

Aluminum clad fuel and target assemblies are stored after irradiation in a water filled concrete disassembly basin. In this basin, the assemblies are often exposed to the basin water environment for several months while awaiting shipment to the 200-Area for processing. Corrosion performance of the aluminum alloys used to clad the target and 
fuel materials has been variable throughout the years of operation. A number of reports have been issued which discuss these corrosion problems and these are listed in the references of this report. Excessive corrosion in the cladding can lead to through wall penetration and the release of tritium and fission products to the disassembly basin water. In contrast, there have been assemblies successfully stored in the basin for extended time periods without through wall penetration of the cladding.

This White Paper presents a review of the documented history of storage performance of aluminum alloys in the disassembly basins at SRS. The paper provides a brief overall description of the aluminum alloys and assemblies, control of water chemistry in the disassembly basin, and review of SRS storage experience. In this review the primary mechanism of corrosion experienced in the disassembly basin, pitting corrosion, will be emphasized. An examination of the successful long-term storage of the Mark 42 assemblies for up to three years is provided to understand the differences between these fuel assemblies and Mark 22's and other aluminum components that have shown through wall penetration in as little as 50-90 days (about 3 months). A brief discussion of other potential corrosion protection techniques usec in the commercial aluminum industry is presented

\section{Aluminum Alloys In SRS Fuel/Target Assemblies}

Aluminum is one of the most thermodynamically reactive metals. Among structural metals, only beryllium and magnesium are more reactive. It owes its excellent corrosion resistance to the barrier oxide film that is bonded strongly to its surface and that, if damaged, re-forms immediately in most environments. ${ }^{1}$

Three aluminum alloys are currently being used in the fabrication of fuel, target tubes, and sleeve housings. The alloy 1100 is co-extruded with a lithium-aluminum core to form an aluminum clad target material. A special alloy, 8001, was developed for high temperature service and is co-extruded with the ${ }^{235} \mathrm{U}$-aluminum core to form the fuel tubes. Various combinations of materials and cladding thicknesses have been used in the many assemblies fabricated for reactor operations over the years. The aluminum alloy 6063 is used in the Universal Sleeve Housing (USH) and in other sleeve housings that are used to direct the cooling water to the assemblies. The primary purpose of the aluminum cladding alloys is to provide the first containment barrier for product release (fission products and tritium). These alloys protect and prevent corrosion of the core target and fuel materials.

The composition of the individual alloys is shown in Table 1.2 The 1100 alloy is $99 \%$ pure aluminum alloy with the silicon plus iron composition not to exceed $1 \%$. Corrosion resistance of this alloy is excellent at low temperatures $\left(<100^{\circ} \mathrm{C}\right)$ in high purity water and increases uniformly at rates which increase with temperature. Above $200^{\circ} \mathrm{C}$ intergranular attack occurs, with resultant more rapid penetration and deterioration of 
T. L. CAPELETTI

SRT-MTS-92-3011

Page 4

April 30, 1992

the metal. ${ }^{3}$ The 8001 alloy was developed for temperatures above $200^{\circ} \mathrm{C}$ by small additions of nickel and iron which give the alloy its superior high temperature corrosion resistance for temperatures up to $350^{\circ} \mathrm{C}$. 4 The 6063 alloy is an aluminum-magnesiumsilicon alloy with moderately high strength and very good resistance to corrosion at low temperatures. Like 1100 , it can develop rapid intergranular corrosion at temperatures above $250^{\circ} \mathrm{C} .5$ The $\mathrm{Mg}_{2} \mathrm{Si}$ phase formed in 6063 is anodic to the aluminum which promotes resistance to pitting corrosion in water at low temperatures. The nickel and iron additions to the 8001 alloy give it the high temperature corrosion resistance, but these elements are cathodic to aluminum at low temperatures and cause the aluminum to be more susceptible to pitting corrosion.

\section{Disassembly Basin And Control of Water Chemistry}

The primary fuel storage facility for fuel irradiated in the SRS reactors is the reactor disassembly basin. There is one disassembly basin associated with each of the reactor areas. The basins have uncoated concrete walls in contact with the basin water which is supplied by the Savannah River. The water is clarified, filtered and then adjusted to a $\mathrm{pH}$ of $7.3 \pm 0.6$ with $\mathrm{HNO}_{3}$ or $\mathrm{NaOH} .6 .7$ The basin water leaches ions from the concrete. These ions continuously increase the corrosivity of the water. In the early operations of the site, the basins were continuously purged with fresh water from the river. In the early 1960's mixed bed ion exchange equipment and sand filters were placed in the reactors to remove fission products from the fuel and ions from the concrete and sludge buildup on the basin floor. These de-ionizers are not operated on a continuous basis, but usually immediately after a discharge to the basin and at other intervals as necessary to maintain water chemistry within operational limits. The basin is purged with fresh river water when the tritium concentration exceeds a preset limit. Tritium enters the basin from the moderator film on fuel recently discharged from the reactors. The operating limits for water chemistry control in the vertical tube storage portion of the basin are shown in Table 2.

Fuel assemblies are suspended from stainless steel hangers. Aluminum clad uranium slugs are stored in stainless steel buckets. The thickness of the clad material for the fuel and target tubes ranges from $0.020-0.030$ inches. The tubes were designed to minimize the amount of aluminum going to waste after separation of nuclear material and to have a cladding thickness which would permit basin storage without penetration. The operating philosophy has been to disassemble the tubes and ship them to Separations within nine months so that leakage of fission products into the basins was minimized. ${ }^{6}$ Basin water chemistry has been controlled in the past and the present, but the prime protection against breaching of the aluminum cladding has always been the shipment of materials to Separations after the minimum required storage period. ${ }^{7,8}$ 
T. L. CAPELETTI

SRT-MTS-92-3011

Page 5

April 30, 1992

\section{Corrosion of Aluminum Alloys}

Corrosion of aluminum alloys used as fuel and target cladding and for sleeve housings and other components, has been a concern since early plant operation. In June 1954, results of slug corrosion tests in a simulated disassembly basin environment were reported. Corrosion penetration up to 0.042 inch was observed on the aluminum jackets of uranium slugs stored for three months in a stainless steel bucket in alum-clarified, filtered Savannah River water at $30-35^{\circ} \mathrm{C} .9$ Although the jackets were only 0.030 to 0.040 inch thick, the tests were continued for an additional three months without positive evidence of a uranium reaction. In a subsequent autoclave test several of the corroded jackets failed in less than 50 hours. The corrosion of these jackets was attributed to the galvanic coupling between the stainless steel bucket and the aluminum slugs. The corrosion was almost completely eliminated by storage in a galvanized steel bucket or an alumin'um-lined bucket.

General corrosion or uniform attack of the aluminum assemblies has not been a problem in the disassembly basin. ${ }^{7}$ The primary mechanism of corrosion over the basin lifetimes has been pitting corrosion. The aluminum alloys are provided protection by the oxide films formed on the alloys. At temperatures above $80^{\circ} \mathrm{C}$, Boehmite $\left(\alpha \mathrm{Al}_{2} \mathrm{O}_{3} \bullet \mathrm{H}_{2} \mathrm{O}\right)$ is formed which will hydrate to Bayerite $\left(\mathrm{B} \mathrm{Al}_{2} \mathrm{O}_{3} \bullet 3 \mathrm{H}_{2} \mathrm{O}\right)$ and very slowly to Gibbsite $\left(\alpha \mathrm{Al}_{2} \mathrm{O}_{3} \cdot 3 \mathrm{H}_{2} \mathrm{O}\right) .^{2}$ In water below $80^{\circ} \mathrm{C}$, hydrated aluminum hydroxide is formed and will gradually convert to Bayerite. Aluminum is well protected by its oxide film in the $\mathrm{pH}$ range of $\mathrm{pH} \mathrm{4-8.5}$ if the oxide is Gibbsite and in the $\mathrm{pH} 4-6$ range if the oxide is Boehmite $\left(>80^{\circ} \mathrm{C}\right)$. Below the $\mathrm{pH}$ ranges given, the oxide and metal dissoives as $\mathrm{Al}^{+3}$. Above the $\mathrm{pH}$ range, the oxide and metal dissolve as $\mathrm{AlO}_{2}^{-}$ions.

Pitting corrosion is localized attack of the aluminum alloy manifested by random formation of pits. For aluminum, pitting corrosion is most commonly caused by halide ions, of which chloride $\left(\mathrm{Cl}^{-}\right)$is the most frequently encountered. The chloride ion can dissolve and penetrate the aluminum oxide films and may accelerate other forms of corrosion, especially pitting. Other ions like copper $\left(\mathrm{Cu}^{+2}\right)$ and iron $\left(\mathrm{Fe}^{+3}\right)$ present at a weak point in the oxide act as efficient cathodes, shifting the corrosion potential above the critical pitting potential and initiate pitting. ${ }^{10,11}$ Iron is not as efficient as copper as a cathode, but there is about 100 times more iron than copper in the water which is introduced by the make-up water and the layer of iron-hydroxide on the basin floor.

It is also possible that pitting is initiated at inclusions, impurities, or weak points in the cladding introduced during fabrication. The problem of pitting corrosion of assemblies is explained if the mechanism described is accepted, because the classic conditions to support pitting - chlorides, heavy metal ions, and relatively stagnant water - exist in the disassembly basin. ${ }^{7}$ 
T. L. CAPELETTI

SRT-MTS-92-3011

Page 6

April 30, 1992

\section{Corrosion Experience of Aluminum Clad Alloys At SRS}

Corrosion of fuel and target tubes of assemblies stored in the 100 Area disassembly basins has been well documented over the plant lifetime. In 1977, an internal memorandum presented a review of the operating history in 1974-1977, a time in which there were four distinct cases of severe corrosion in the K-Area disassembly basin. 10 In March 1974, Mark 18A's were discharged to the disassembly basin followed by an immediate tritium release. Subsequent inspection five months later revealed severe corrosion and cladding penetration. In March 1975, Mark 22 outer targets were discharged and again a tritium release occurred. Inspection of these a year later showed cracks and pits that were actively evolving tritium. Due to the near time release of tritium, there was some speculation that corrosion on these assemblies could have occurred in the reactor.

Several Mark 53A assemblies discharged in June 1975 were inspected in August, 1975 for corrosion similar to that seen earlier on tubes in P \& C basins. Mild corrosion was noticed, but no clad penetration. By October, the corrosion increased and penetration of the clad was responsible for alpha release. The final incident involved Mark $18 \mathrm{~F}$ assemblies discharged in October 1976. Inspection of these tubes in January, 1977 revealed severe corrosion and penetration of the cladding.

The conclusion reached in this review was that corrosion rates were great enough to cause cladding penetration within three months. If they were interpreting the activity releases properly, penetration possibly occurred in as little as one month. Other assemblies discharged to the basin during this time period showed little corrosion.

In June 1977, Test Authorization 1-2024 was issued to determine corrosion variables for aluminum clad and target assemblies stored in the 100-Area disassembly basins. 12 A 1977 study of the failure of a large number of sleeve target (Mark 53A) and fuel (Mark 22) assemblies stored in the disassembly basin identified pitting corrosion as the failure mechanism. ${ }^{13}$ The primary cause of pitting corrosion was identified as the galvanic cell formed by the contact between the stainless steel hanger plate used to support the assembly and the aluminum top fitting of the assembly. Other contributors to the pitting corrosion were identified as high chloride ion concentration, low $\mathrm{pH}$, and the presence of copper ions in the basin water. Recommendations from the results of these failure analyses and Test Authorization No. 1-2024 were to provide electrically insulated disassembly hangers to eliminate the galvanic couple between the stainless steel hanger and the aluminum assembly. ${ }^{14}$ In addition, the chloride ion concentration in the basins was recommended to be reduced to a level of about $5 \mathrm{ppm}$.

Accelerated corrosion of target assemblies in the disassembly basin is discussed in a 1980 report. $^{7}$ This memorandum reviewed the storage of Mark 53A and Mark 22 fuel assemblies of the 1974-1977 era and provided a technical basis for the corrosion failures. The document described the examinations and tests included in the 
T. L. CAPELETTI

SRT-MTS-92-3011

Page 7

April 30, 1992

investigation of the problem. A committee, formed to determine the cause of accelerated corrosion in the basins, identified the following contributors to the accelerated corrosion: poor cladding material, high concentrations of iron and chloride ions in the water, a galvanic couple between the aluminum assemblies and the stainless steel hangers, and scratches in the oxide layer on the cladding surface. The basin conditions were adjusted from $6.5 \pm 0.8$ to $7.3 \pm 0.6$ to reduce the pitting and the solubility of heavy metal ions. Chloride concentration was reduced from $25 \mathrm{ppm}$ to $5 \mathrm{ppm}$ by reducing additions of $\mathrm{NaOCl}$. With these changes initiated in 1978, there were no accelerated corrosion problems during the next two years prior to this report.

Following a stop work order in January 1989, the moderator chemistry in K-Reactor exceeded limits for reactor operations. The $\mathrm{pH}$ of the moderator was lowered from a nominal 4.7 to between 3.5-4.0. Concentrations of ions in the moderator increased from $30 \mathrm{ppb}$ to $200 \mathrm{ppb}$ for chloride and $100 \mathrm{ppb}$ to $4000 \mathrm{ppb}$ for the aluminum. ${ }^{15}$ As a result of the out-of-specification conditions, a concern arose over the possible corrosion of the aluminum components. Sleeve housings of 6063 were selected for analysis and considered representative of aluminum components in the reactor. These housings were metallurgically analyzed for pitting corrosion. Sixteen of the twenty-four sections from the first set of six sleeve housings showed evidence of pitting corrosion, but no evidence of general or crevice corrosion. Seven of the pits on four different sections had penetrated the wall of the tubes. Circumstantial evidence from this study and prior evidence led to the conclusion that the pitting corrosion did not occur in the moderator, but probably occurred during the 25 to 70 days that the sleeve housings were stored in the disassembly basin of $105-\mathrm{K}$ prior to the examination. ${ }^{16}$

In order to confirm this hypothesis, two additional housings were cut into sections and immersed in the disassembly basin. Two sections from each housing were removed in less than two weeks and the rest remained in the basin for approximately three months. There was no pitting corrosion observed on samples removed after two weeks, but the samples which remained in the basin for 93 days showed four through-wall pits. ${ }^{17}$

Based on these results, coupon holders containing surveillance samples were installed in the L-Reactor disassembly basin in May, 1991.19 The first follow-up visual observation of the coupons in the L-Reactor basin was conducted in June, 1991 (approximately 42 days after the coupons were placed in the basin). The basin water chemistry remained within specification throughout the exposure period. Visual observation of the coupons showed formation of white deposits, indicative of corrosion, on the surface of the Type 8001 aluminum coupons. The coupons were removed from the coupon holder and transported to SRTC for analysis. Microscopic analysis indicated that the deepest pits formed in the 8001 alloy were on the order of 30 mils deep (the thickness of the cladding on a fuel tube). Little corrosion was observed on the Type 1100 or 6063 aluminum coupons. These observations supported the earlier results obtained from field and laboratory tests on the corrosion of aluminum alloys and emphasized the need for further examinations. 
T. L. CAPELETTI

SRT-MTS-92-3011

Page 8

April 30, 1992

As part of the surveillance activities to better understand the corrosion of aluminum cladding alloys in the disassembly basin water environment, components from actual fuel and target tubes were placed in the K Reactor basin in November, 1991.19 These samples were removed after 107 days exposure in basin water which stayed within operational limits except for one month in which pH rose slightly above the upper limit of 7.9 to a value of $\mathrm{pH} 8.3$. The samples were cleaned prior to insertion in the basin using the Oakite process, but were not given the steam drying treatment. However, the components had a thin protective oxide coating which was formed in air. The oxide coating formed in the six minutes of steam drying on actual fuel tubes is thin compared to that formed at high temperatures of reactor irradiations or simple immersion in cold water.

A preliminary analysis of the specimens showed the 1100 and 8001 aluminum components had undergone significant oxidation and pitting corrosion. One of the 8001 alloys had several large pits about $1 / 4$ inches in diameter and one at least 39 mils deep, apparently penetrating the clad. The observed pitting in the 1100 alloy was smaller in diameter, with pits of 23 mils depth measured. There was mild corrosion product on the 6063 coupons included in the study.

\section{Mark 42 Disassembly Basin Storage}

Fifty-six Mark 42 assemblies, designed to produce $242 \mathrm{Pu}$, were irradiated in a series of seven different irradiations betwe An August, 1980, and November, 1984. The assemblies were discharged to the $P$ disassembly basin for periods between 2-12 weeks between irradiations for a total exposure of 5-7 months. The final discharge to the basin for storage occurred in November of 1984.20 In April, 1987, after a total exposure of almost three years, a decision was made to remove the assemblies which had been stored in their sleeve housing and store them in individual, water-filled sealed aluminum containers. The successful storage of these particular assemblies has been verified by low fission product activity during the storage period. Spikes of high fission activity are indicative of through wall penetration of the cladding. The success of these particular assemblies justified a further investigation to determine the differences in the Mark 42's and the Mark 22's which have experienced some pitting corrosion problems over the years.

The Mark 42 assembly consists of three concentric fuel tubes with $\mathrm{PuO}_{2}$-Al powdèr metallurgy cores, each tube clad in 6063 aluminum alloy. These fuel tubes are contained in a 6063 aluminum target sleeve-housing. The Mark 22 assembly, on the other hand, consists of four concentric tubes. The outer and inner target tubes are clad with 1100 aluminum alloy and the outer and inner fuel tubes are clad with the 8001 aluminum alloy. The target or fuel sleeve-housing is 6063 aluminum. 
T. L. CAPELETTI

SRT-MTS-92-3011

Page 9

April 30, 1992

The Mark 42 alloys were stored inside their sleeve-housings in the disassembly basin. The assemblies were stored on stainless steel hangers attached to the sleeve-housings and not the assemblies themselves. Mark 22 assemblies are not, as a general rule, stored inside their sleeve-housings and the stainless steel hangers are in direct contact with the assemblies.

Storage of the Mark 42 alloys in the individual sleeve-housings apparently minimized any corrosion. The stainless steel hanger was allowed to only contact the sleeve-housing. At least partial isolation of the assembly, itself, from the galvanic couple of the stainless steel hanger, may have played a key role in preventing the corrosion. In addition, discharge of the assembly inside the sleeve-housing minimized damage in the form of scratches and dents which remove the protective oxide coating and exposed bare aluminum. Otherwise, containing the assemblies inside the sleeve-housing could promote corrosion with more stagnant water conditions and possible crevices between the ribs and tubes of the sleeve and assembly.

The pitting susceptibility of the 8001 alloy is much greater than the 6063 alloy and the 1100 alloy. This was recognized in earlier studies and documented in a DuPont Wilunington Technical-Process Meeting on April 2, 1976.21 The iron and nickel alloying elements put into the aluminum to give it high temperature corrosion properties actually promote pitting of the aluminum in water a low temperatures. At high temperature, the elements give anodic protection but are cathodic at low temperatures. ${ }^{4}$ The 8001 alloy contains no magnesium, which is used in 6063 to retard pitting corrosion and increase strength.

Another factor influencing the improved corrosive behavior of the Mark 42 assemblies might have been the seven different irradiations this fuel experienced. The assemblies were taken to the maximum operations temperature, held at temperature for varying time intervals, and then cooled and discharged to the disassembly basin. The protective nature of the oxide could have been better than that of a single irradiation of different time interval.

In summary, the Mark 42 assemblies were fabricated from a different aluminum alloy system which was less susceptible to pitting corrosion in the disassembly water environment. It was stored in a different manner inside the sleeve-housing to minimize damage to the oxide coating and minimize the galvanic couple to the assembly. The multiple irradiation schedule could have provided a more protective, or at least different, oxide thickness and characteristic from normal Mark 22 irradiation and storage. These differences likely played a key role in a better corrosion performance for the Mark 42's versus the Mark 22's under basin water storage environments. The basin water chemistry during storage of Mark 42's was generally within operating limits and not different from normal Mark 22 storage. 
T. L. CAPELETTI

SRT-MTS-92-3011

Page 10

April 30, 1992

\section{Alternate Corrosion Protection Techniques}

\section{Cathodic Protection}

Several other corrosion protection techniques have been suggested over the years for potential use with the SRS aluminum assemblies. A brief discussion of these techniques as they apply to the SRS particular application is provided in this review.

Aluminum alloy parts, assemblies, structures, and pipelines are of ten cathodically protected from corrosion by anode made of more anodic metals or made anodic by using impressed potentials. 1 Sacrificial anodes of zinc, or magnesium, and/or zinc-aluminum alloys are used to protect equipment in chemical plants. Such protection is most successful in electrolytes in the pH range of 4 to 8.5 , which is the so-called neutral range. The general experience in industry is that cathodic protection is effective in preventing or greatly reducing several types of corrosion.

The practicality of using cathodic protection for the SRS assemblies would require a scoping study by subcontractors who are experts in the field. There are currently some cathodic protection systems on site, but commercial experts have designed and implemented them. Since the sacrificial anodes have to essentially have a "line-of-site" to the surface they are protecting, protection of the interior surfaces of the individual fuel/target tubes would be difficult. Anodes would have to be inserted into individual narrow channels and suspended by wire carrying D.C. electrical current, all in the water of the disassembly basin. Because of the complex geometry of the fuel assemblies, cathodic protection to $100 \%$ of the interior surfaces may not be feasible. 2

Protection of the exterior sleeve-housing is likely possible as the surfaces are more readily available for exposure to the anodes. Another consideration would be the assurances that any anodes placed inside the channels of the fuel assembly were removed from the assembly if it were to be later sent back to the reactor for additional irradiation.

Extensive monitoring and control of the system electrical potentials would have to be carefully performed because excessive potentials can cause an increased alkalinity at the aluminum surface with subsequent significant corrosion.

\section{Corrosion Inhibitors}

An inhibitor can be described as a chemical substance or combination of substances that, when present in the environment, prevents or reduces corrosion without significant reaction with the components of the environment. 1 The use of inhibitors for protection of aluminum in acids and water environments is found in the literature. Among those inhibitors mentioned which might be of interest for pro ecting SRS aluminum alloys are sodium dichromate, sodium silicate, disodium hydroden phosphate, zinc chromate, and 
T. L. CAPELETTI

SRT-MTS-92-3011

Page 11

April 30, 1992

zinc polyphosphate.1, 23 Inhibitors are specific in terms of metal alloys, environment, temperatures, and concentration range. The concentration and type of innibitor to be used in a specific corrosive environment is usually determined by empirical testing. It is important to use enough inhibitor because many inhibitors actually accelerate corrosion, particularly pitting corrosion. ${ }^{24}$

The use of an inhibitor in the disassembly basins at SRS presents particularly stringent limitations. The nuclear compatibility of the inhibitor which could get back to the moderator if the assemblies were ever re-charged to the reactor must be considered. Materials containing zinc and chrome could present problems when irradiated. If these inhibitors get into the waste streams during the separations process, other problems have to be considered. A previous attempt to use lithium silicate to reduce corrosion of fuel tubes in an in-reactor test resulted in some reduction of oxide film thickness. ${ }^{25}$ The system was never implemented because 300 grams of insoluble silica could not be accounted for. It apparently reacted with alumina to form aluminosilicate and was removed by the filters of the ion exchange columns. ${ }^{26}$

The use of inhibitors in the disassembly basins is not compatible with the use of deionizers which are currently used to remove the heavy metal ions, etc. from the water. Since the de-ionizers would be continuously removing the inhibitor from the water, it would be difficult to keep the concentration at the appropriate, protective level. The inhibitor would contribute to depletion of the resin beds and could possibly cause damage to these beds. Based on results of this brief review, the use of inhibitors does not appear to offer advantages for improved corrosion protection in our application.

\section{Alternate Basin Storage}

Another consideration for storage of SRS aluminum clad assemblies which might improve corrosion performance of the alloj's is storage in the Receiving Basin for Offsite Fuels (RBOF). 6 This basin has the capability to store stainless steel, zirconium clad, and aluminum fuels. The water chernistry in this facility is much better controlled than in the disassembly basins. This chemistry is shown in Table 3. The basin is an epoxycoated, concrete pool with a stainless steel-lined bottom. Aluminum racks to reduce the galvanic action are used to store aluminum fuels. The mixed bed ion exchange equipment is operated continuously tc remove fission products, maintain deionized water and keep the pH limits between 5.9. The basin water is re-cycled through the deionizers in RBOF, whereas disassembly basins are purged with make-up water from the Savannah River.

Long-term storage of aluminum clad fuel and target assemblies has been successful in RBOF. Although fuels have been generally processed within a year, some aluminum clad fuels have been stored in RBOF for more than ten years without evidence of significant cladding penetration. ${ }^{6}$ 
T. L. CAPELETTI

SRT-MTS-92-3011

Page 12

April 30, 1992

Future availability of enough storage sites in RBOF for new on-site irradiated fuels will have to be determined. In addition, adequate shipping casks for transport to RBOF must be available as well as equipment to receive future on-site irradiated assemblies.

\section{Conclusions}

Based on this review of storage of aluminum clad fuel and target alloys in the reactor disassembly basins at SRS, corrosion is an ongoing concern. Documented history dating back to 1954 provides a significant number of events in which pitting corrosion has penetrated the cladding on stored assemblies representing several combinations of aluminum alloys. The time periods between 1974-1977 saw at least four distinct cases on corrosion in which cladding was penetrated and fission products released to the basin. These incidents and corrosion studies conducted over the last several years indicate that under existing operating conditions and basin water chemistry environments, there is a high probability for pitting corrosion to occur on assemblies stored for long terms. Evidence from previous test and actual assemblies stored in the basin indicates that through wall penetration can occur in three months or possibly sooner, depending on water conditions.

Evidence points to the galvanic couple between the stainless steel hangers and the assemblies playing a key role in promoting the corrosion process. Recommendations have been made to change these hangers to aluminum; these need to be implemented. Sludge on the basin floor continuously provides sources of heavy metal ions to the water. These ions and chloride ions speed the pitting initiation process up. Ion concentration should be as low as possible to minimize the pitting corrosion. The de-ionizers should be operated in a more continuous mode of operation to maintain low ion concentrations. All efforts should be put forth to purify the basin water chemistry environment as evidence documents that ROBF water purity can support storage of aluminum for periods up to ten years without corrosion problems. The reactor moderator chemistry is even purer as shown in Table 4 and fuel and target clad corrosion problems associated with this environment have been essentially non-existent over the years of operation. 


\section{T. L. CAPELETTI}

SRT-MTS-92-3011

Page 13

April 30, 1992

\section{References}

1. Metals Handbook, Vol. 13, "Corrosion," 9th Ed. p583-608, Metals Park, Oh, 1987.

2. R. S. Ondrejcin, "Corrosion of Aluminum Reactor Components (U), "WSRC-RP-89539, SRL-MTD-890269, July 17, 1989.

3. J. E. Draley and W. I. Ruther, "Aqueous Corrosion of Aluminum, Part 1 Behavior of 1100 Alloy, "Corrosion, Vol. 12 (No. 9), 1956, p441 t.

4. J. E. Draley and W. E. Ruther, "Aqueous Corrosion of Aluminum, Part 2 Methods of Protection Above $200^{\circ} \mathrm{C}$, "Corrosion, Vol. 12 (No. 10), 1956, p480t.

5. R. P. Taylor, "Irradiation of Mark 42 Assemblies, "SRS Test Authorization 1-2084, August 1, 1980.

6. M. C. Thompson and T. S. Rudisill, "Al Corrosion in SRS Storage Basins (U)," WSRC-TR-92-187, April 9, 1992.

7. C. D. Wollam, "Accelerated Corrosion of Target Assemblies in the Disassembly Basins," RTR-1939, October 15, 1980.

8. J. J. Banks, "Irradiated Slug Corrosion Study (U)," WSRC-TR-90-42-030, May 30, 1991.

9. A. H. Peters, "Fuel Jacket Corrosion in Plant Disassembly Basins," DP-57, June 1954.

10. M. W. Zacharias - D. R. Becker, "Disassembly Basin Aluminum," RTR-1727, August 31, 1977.

11. Davies, D. E, "Pitting of Aluminum in Synethetic Waters,"J. Applied Chemistry, 9, 651 (1959).

12. D. R. Becker, "Disassembly Basin Corrosion Tests, SRS Test Authorization 12024," June 17, 1977.

13. D. A. Ward, "Corrosion of Assemblies in the Disassembly Basin," RTM-4221, December 27, 1978.

14. J. T. Berry, "Disassembly Basin Corrosion Tests," DPSOX 9159, February 9, 1979.

15. G. R. Caskey, Jr. and The Reactor Corrosion Mitigation Committee, "Aluminum Components in K-Reactor (U), "SRL-MTS-900046, February 28, 1990. 
T. L. CAPELETTI

SRT-MTS-92-3011

Page 14

April 30, 1992

16. D. T. Rankin, "Corrosion of K-Tank Aluminum Components," SRL-MTS-900040, February 20, 1990.

17. R. S. Ondrejcin and D. E Rawl, "Corrosion of Aluminum Components in K-Reactor (U), "WSRC-TR-90-291, July 13, 1990.

18. J. E. Marra, "Reactor Corrosion Mitigation Committee (RCMC) Meeting Minutes July 29, 1991 (U),"SRL-MTS-913024, July 29, 1991.

19. J. P. Howell, et al., "Corrosion of Mark 22 Aluminum Components in the KReactor Disassembly Basin: Preliminary Analysis of Specimens Removed in March, 1992 (U)," SRT-MTS-92-3002 (U), April 3, 1992.

20. G. F. Merz, "Mark 42 Long Term Storage," RTM-4849, April 22, 1987.

21. J. R. Hester, "Cladding Corrosion in 100-Area Basins," Undocumented Memorandum of Slides presented at DuPont - Wilmington Technical - Process Meeting, April 2, 1976.

22. Vormelker, P.R., "Use of Cathodic Protection for the K 14.1 Charge," Undocumented Inter-Office Memorandum, April 23, 1992.

23. S. B. Twiss, and J. D. Guttenplan, "Corrosion Testing of Aluminum," Corrosion, $12,263 t$ and $311 t$, June and July, 1956.

24. M. Fontana and Norbert D. Greene, Corrosion Engineering, 2nd Ed., McGraw-Hill Book Co., p. 198-199.

25. R. S. Ondrejcin, "Silicates as Inhibitors of Aluminum Corrosion in Savannah River Reactors, "DP-1197, December, 1969.

26. R. S. Ondrejcin, "Pretreatment of Nuclear Fuel Cladding at SRS (U)," WSRC-TR-90583, December 10, 1990. 
TABLE I

Reactor Aluminum Alloy Components

\begin{tabular}{|l|l|l|l|l|l|}
\hline Alloy & AT & SI & Fe & NI & Mg \\
\hline \multicolumn{7}{|c|}{} \\
\hline 1100 & $99.0^{*}$ & a & a & - & - \\
\hline 8001 & b & b & 0.6 & 1.1 & - \\
\hline 6063 & 98.9 & 0.4 & - & - & 0.7 \\
\hline
\end{tabular}

\footnotetext{
* Minimum

a $\quad \mathrm{Si}+\mathrm{Fe}=1 \% \mathrm{Max}$.

b 1100 Alloy $+\mathrm{Fe}$ and $\mathrm{Ni}$
}

TABLE II

Water Chemistry

Vertical Tube Storage Operating Limits

\begin{tabular}{|c|c|c|c|}
\hline Analysis & Lower & Upper & Units \\
\hline Alpha & 0 & 10 & $\mathrm{C} / \mathrm{M} / \mathrm{MI}$ \\
\hline Conductivity & $\overline{0}$ & 400 & $\mu \mathrm{MHO} / \mathrm{CM}$ \\
\hline$\overline{\mathrm{pH}}$ & 6.7 & 7.9 & \\
\hline Tritium & $\overline{0}$ & 0.40 & $\mu \mathrm{Ci} / \mathrm{MI}$ \\
\hline $\mathrm{Cl}^{-}$ & $\overline{0}$ & 20 & $\mathrm{ppm}$ \\
\hline $\mathrm{NO}_{3}^{-}$ & $\overline{0}$ & 30 & ppm \\
\hline$\overline{\mathrm{NO}_{2}^{-}}$ & 0 & 30 & $\mathrm{ppm}$ \\
\hline $\mathrm{SO}_{4}^{-}$ & $\overline{0}$ & 30 & pim \\
\hline$\overline{\mathrm{Al}}$ & 0 & $\overline{0.1}$ & ppm \\
\hline $\mathrm{Fe}$ & $\overline{0}$ & 0.1 & ppm \\
\hline $\mathrm{Cu}$ & $\overline{0}$ & 0.1 & $\mathrm{ppm}$ \\
\hline
\end{tabular}


T. L. CAPELETTI

SRT-MTS-92-3011

Page 16

April 30, 1992

TABLE III

RBOF Basin Water Chemistry Limits

\begin{tabular}{|c|c|c|c|}
\hline Analysis & Lower & Upper & Units \\
\hline $\mathrm{pH}$ & 5 & 9 & \\
\hline $\mathrm{T}$ & - & 40 & ${ }^{\circ} \mathrm{C}$ \\
\hline $\mathrm{Cu}$ & & 0.01 & $\mathrm{ppm}$ \\
\hline $\mathrm{Hg}$ & & 0.01 & $\mathrm{ppm}$ \\
\hline \multicolumn{3}{|c|}{ Typical } & Analyses \\
\hline Conductivity & & $<1$ & $\mu \mathrm{MHO} / \mathrm{CM}$ \\
\hline $\mathrm{Cl}$ & & $<10$ & $\mathrm{ppb}$ \\
\hline $\mathrm{Hg}$ & & $<2$ & $\mathrm{ppb}$ \\
\hline $\mathrm{Cu}$ & & $<2$ & $\mathrm{ppb}$ \\
\hline $\mathrm{Fe}$ & & $<2$ & $\mathrm{ppm}$ \\
\hline $\mathrm{Al}$ & & $<2$ & $\mathrm{ppm}$ \\
\hline Turbidity & & 1 & $\mathrm{NTU}$ \\
\hline
\end{tabular}

TABLE IV

Reactor Moderator Water Chemistry Operating Limit

\begin{tabular}{|c|c|c|c|}
\hline Analysis & Lower & Upper & Units \\
\hline $\mathrm{pD}$ & 5.0 & 5.2 & \\
\hline Conductivity & 1.9 & 3.0 & $\mu \mathrm{S} / \mathrm{cm} @ 25^{\circ} \mathrm{C}$ \\
\hline Nitrate & 500 & 630 & $\mathrm{ppb}$ \\
\hline Nitrite & & $<30$ & $\mathrm{ppb}$ \\
\hline Chloride & & $<30$ & $\mathrm{ppb}$ \\
\hline Sulfate & & $<50$ & $\mathrm{ppb}$ \\
\hline Oxalate & & $<50$ & $\mathrm{ppb}$ \\
\hline Peroxide & & $<1000$ & $\mathrm{ppb}$ \\
\hline B- $\gamma$ & & $<2 \times 10^{6}$ & $\mathrm{c} / \mathrm{min} / \mathrm{mL}$ \\
\hline Turvidity & & $<0.5$ & $\mathrm{NTU}$ \\
\hline
\end{tabular}



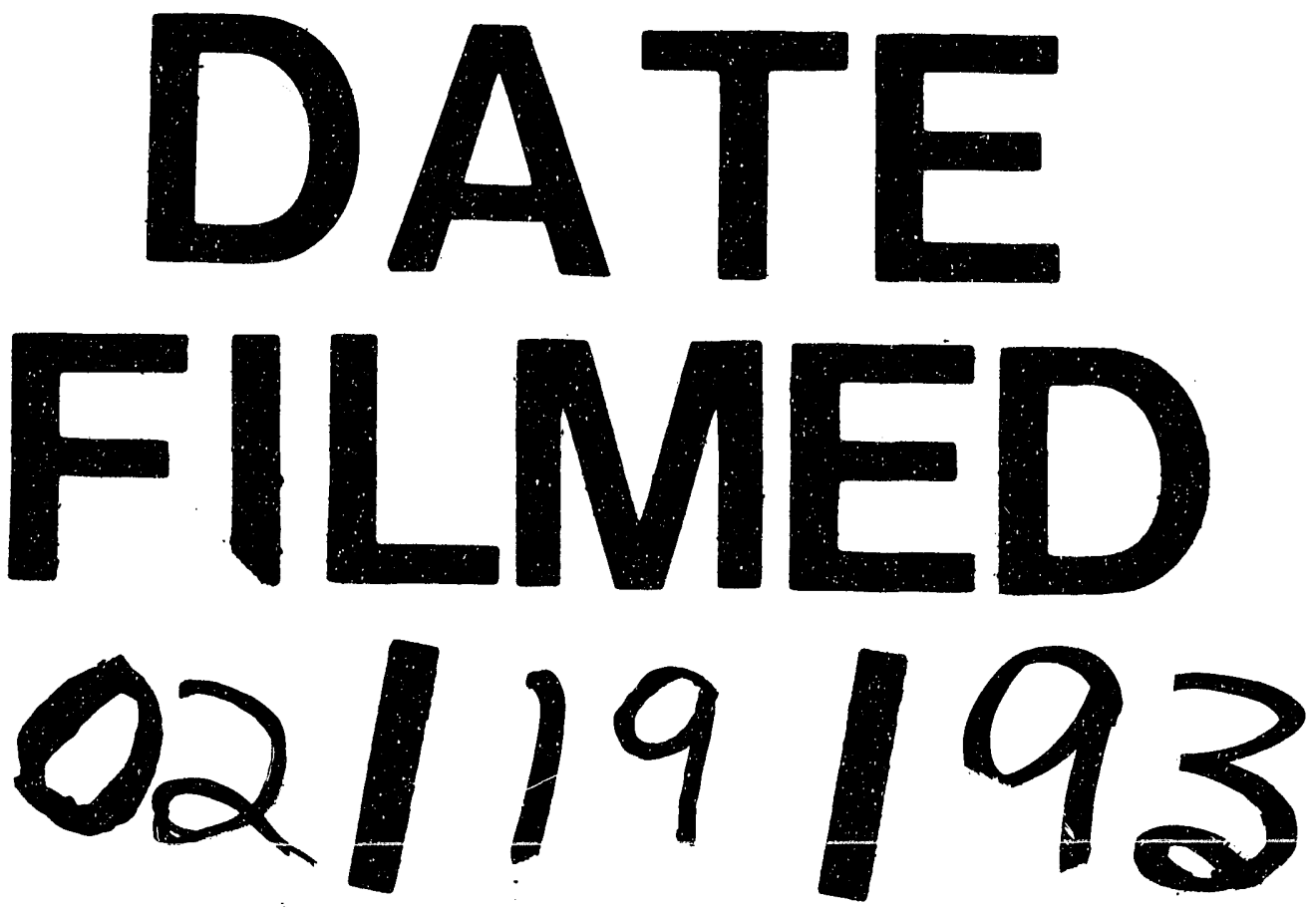
